International Journal of Business Management and Economic Review

Vol. 5, No. 01; 2022

ISSN: 2581-4664

\title{
THE EFFECT OF PUBLIC SERVICE MOTIVATION AND JOB SATISFACTION ON EMPLOYEE PERFORMANCE WITH EMPLOYEE COMMITMENT AS A MEDIATION VARIABLE AT JABAL GHAFUR UNIVERSITY
}

\author{
*Rahmi Soeraiya, Sofyan and Shabri \\ Management Department, Universitas Syiah Kuala, Indonesia \\ http://doi.org/10.35409/IJBMER.2022.3355
}

\begin{abstract}
This study aims to examine the effect of public service motivation and job satisfaction on employee performance with employee commitment as a mediation variable at Jabal Ghafur University. The population was all employees of Jabal Ghafur University, totaling 41 employees. The number of samples was determined as 41 employees through the census technique. Data were analyzed through Partial Least Square (PLS). The direct test results conclude that public service motivation affects employee commitment and employee performance, Job satisfaction affects employee commitment but not employee performance, and Employee commitment affects employee performance. These results prove that the model for improving employee performance at Jabal Ghafur University is a function of increasing Public Service Motivation, Job Satisfaction, and Employee Commitment. An increase in Public Service Motivation can have a direct impact on improving performance and it can also be through an increase in commitment first, while an increase in satisfaction will only result in an increase in commitment first and will then have an impact on increasing performance.
\end{abstract}

Keyword: Public Service Motivation, Job Satisfaction, Employee Commitment, Employee Performance.

\section{INTRODUCTION}

In Aceh, Indonesia, there are several universities, both state and private universities. Jabal Ghafur Sigli University is one of the private universities in Aceh which is located in the Pidie district. In this district, there are no state universities, only private universities, namely Jabal Ghafur University and Jabal Ghafur University Nursing Academy, and PTI AL-Hilal Sigli, so that the competition between PTS becomes more stringent.

In a dynamic organization, performance is one of the references for the realization of the vision and mission that has been set. This will have a very significant impact on the success of an organization. Robbins (2016) interpreted employee performance is as the results of work or activities which contain three aspects, namely: clarity of tasks or work that is their responsibility, clarity of expected results from a job or function, and clarity of time needed to complete work so that the expected results can be realized. Henceforth employee performance in this study will often be called performance.

Performance appraisal at Jabal Ghafur University (UNIGHA) uses a work behavior assessment and work planning assessment or known as Employee Work Target (SKP). From the results of the assessment, the scores were grouped by the predicate, namely: very good $(\geq 91)$, good 
International Journal of Business Management and Economic Review

Vol. 5, No. 01; 2022

ISSN: 2581-4664

(76-90), adequate (61-75), poor (51-60), and poor $(\leq 50)$.

Table 1. Work Target of 2018-2020

\begin{tabular}{|l|l|l|l|l|}
\hline No. & Year & $\begin{array}{l}\text { Number } \\
\text { employees }\end{array}$ & $\begin{array}{l}\text { Average } \\
\text { Performance assessment (\%) }\end{array}$ & Information \\
\hline 1. & 2018 & 30 & 82.01 & Well \\
\hline 2. & 2019 & 38 & 84.34 & Well \\
\hline 3. & 2020 & 41 & 81.03 & Well \\
\hline
\end{tabular}

Source: Jabal Ghafur University (UNIGHA), 2021

Based on Table 1 above, reveals that the percentage of work quality assessment results is not following what is expected, namely getting a very good predicate $(\geq 91)$, even in 2020 the level of performance quality has decreased to the position of $81.03 \%$. This still requires improvement in the quality of performance expected by the University of Jabal Ghafur.

High commitment makes individuals care about the fate of the organization and try to make the organization a better direction. Employee commitment plays an important role in improving performance. According to (Sopiah \& Sangadji, 2018) employee commitment is an attitude that reflects the likes or dislikes of employees towards the organization. Without effective employee commitment from employees, Unigha Jabal Ghafur Sigli cannot provide quality services to students, resulting in sub-optimal performance.

High and low employee commitment is strongly influenced by employee job satisfaction to improve performance is needed. Job satisfaction is the dream of every individual who has worked. Each employee has a different level of satisfaction according to their values. (Robbins \& Judge, 2017) explain from a review of 300 studies that there is a fairly strong correlation between job satisfaction and performance. Whereas we move from the individual to the organizational level, we also find support for the performance-satisfaction relationship. When we collect satisfaction and performance data for the organization as a whole,

(Rainey \& Steinbauer, 1999) reveal that public service motivation is a general motivation possessed by a bureaucrat to prioritize the interests of the community to serve the needs of the community, nation, state, or for the sake of humanity. Meanwhile, (Vandenabeele, Scheepers, \& Hondeghem, 2006) define PSM as a belief, values, and attitudes based on personal interests or organizational interests that are concerned with the interests of broader political entities and which encouraged through interaction with the public as well as motivation to achieve targets.

Observing some of the interesting things mentioned above, the authors are interested in researching The Effect of Public Service Motivation and Job Satisfaction on Employee Performance at Jabal Ghafur University with Employee Commitment as Mediation Variables at Jabal Ghafur University".

\section{STUDY OF LITERATURE}

Employee performance

Performance is the work achieved by every civil servant in the organization/unit following the employee performance system and work behavior (RI PP, 2019). Meanwhile, according to (Suwanto \& Priansa, 2016) Performance or work performance is the result achieved by a person according to the applicable size, within a certain period, concerning work and behavior, and actions. In other words, performance is the work achieved by a person in carrying out his duties 
International Journal of Business Management and Economic Review

Vol. 5, No. 01; 2022

ISSN: 2581-4664

and obligations. Thus the issue of performance is also related to a person's ability to develop his abilities to be able to work following organizational goals.

The dimensions and indicators of performance according to (Gomes, 2003) are as follows:

1. Quantity of Work

a. Amount of work done

b. The amount of work accomplished in a certain period

2. Quality of Work

a. Skills in carrying out tasks

b. The quality achieved based on the requirements and suitability and readiness

3. Job Knowledge

a. Extensive knowledge about work

b. The breadth of knowledge about skills

4. Creativeness

a. Idea skill

b. Ability to solve problems that arise

\section{Employee commitment}

(Kreitner \& Kinicki, 2013) also define employee commitment as the level of individual identification with the organization and commitment to achieving the goals set by the organization. (Luthans, 2013) states that employee commitment is an attitude that reflects employee loyalty to the organization and a continuous process in which organizational members express their concern for the organization and its success and continuous progress.

Research conducted by (Salwa, Away, \& Tabrani, 2018) found that commitment, integrity, and competence have a positive effect on employee performance and Aceh KIP performance. Employee performance can mediate the effect of employee commitment, integrity, and competence on the performance of the agency. (Respatiningsih \& Sudirjo, 2015) found a significant impact of organizational commitment on employee performance; a significant impact of motivation on employee performance; a significant impact of capabilities on employee performance; and a significant impact of job satisfaction on employee performance.

(Robbins \& Judge, 2017) said employee commitment is defined in three different themes, namely commitment as an attachment to the organization, commitment is seen as a cost incurred if leaving the organization, and commitment as an obligation to remain in the organization. The indicators of organizational affective commitment according to (Meyer \& Allen, 1997) are as follows:

a. Employees feel happy to spend their careers at the company

b. Employees feel part of the company family

c. Employees like to talk about the company with colleagues when they are not working.

d. Employees find it easy to adapt while working in the company

e. Employees feel very emotionally attached to the company

The indicators of continuity commitment according to (Meyer \& Allen, 1997) are as follows:

a. Employees have given optimal efforts while working in the company so that employees still want to work at the company

b. Employees don't have many choices of replacement companies so they don't think about leaving the company 


\section{International Journal of Business Management and Economic Review}

Vol. 5, No. 01; 2022

ISSN: 2581-4664

c. Currently, employees feel the need to work in the company

The indicators of normative commitment according to (Meyer \& Allen, 1997) are as follows:

a. Employees feel they have many advantages working in the company

b. Employees will not leave the company because they still have obligations

c. The company deserves employee loyalty

d. Employees will feel guilty if they leave the company

\section{Public Service Motivation}

(Jankingthong \& Rurkkhum, 2012) define Public Service Motivation as an individual's tendency to respond to the unique basic motives found in public institutions and organizations. (Crewson, 1997) argued that Public Service Motivation is an individual service orientation to be useful for the community, an orientation to help others, and a passion for achievement that is intrinsic or service-oriented. (Perry \& Hondeghem, 2008) explained that research on public service motivation has received a lot of attention from researchers in the last two decades, and researchers' interest in this continues to grow from time to time. The problem of public service motivation has often been a topic of research in the West to find and understand the ideal concept for public service and in efforts to develop the science of public administration and management.

(Lewicka, Glinska-Newes, Morrow, \& Gorka, 2018). revealed that public service motivation is the basis for the productivity of an organization so that employee performance is maintained. Public service motivation and employee competence are some of the efforts that can be made to improve performance in the organization because both are also factors that affect performance (Saputra \& Sripto, 2018).

There are four dimensions to measure the level of motivation of public services according to (Perry \& Hondeghem, 2008), namely:

1. Interest in public policy

a. Achieve work performance that can be achieved

b. Achieve inner or personal satisfaction in carrying out tasks

2. Responsibility to the public interest and obligations as a citizen (commitment to the public interest and civil duty)

a. Serve the public sincerely

b. Prioritizing social interests

3. Feelings of sympathy or pity (compassion)

a. Caring for the interests of others (altruism)

b. Attitude to feel the feelings of others (empathy)

c. Have faith in morals (moral conviction)

4. self-sacrifice

a. High love for the homeland

b. Responsibility on duty

c. Loyalty to the country

\section{Job satisfaction}

Job satisfaction according to (Afriani \& Kasmiruddin, 2017) "is a pleasant or unpleasant emotional state towards work, job satisfaction reflects one's feelings towards his work. According to (Soetrisno, 2016) job satisfaction is a fairly interesting and important issue, because it has 
Vol. 5, No. 01; 2022

ISSN: 2581-4664

proven to be of great benefit to the interests of individuals, industry, and society. For individuals, research on the causes and sources of job satisfaction enables efforts to increase their happiness in life."

(Fadlallh, 2015) in his research shows that job satisfaction affects employee performance. All members of the teaching staff strongly agree that whenever the better come (working conditions, pay and promotions, and employment relationships) there is a higher job. Transportation sector employees are motivated by proper training, reward system, earned income, personal policies, enhanced avenues of promotion all these things are related to job satisfaction which improves employee performance in the transportation sector (Ram, 2017). This study shows that job satisfaction has a significant relationship with role performance and innovation (Dizgah, Chegini, \& Bisokhan, 2012).

\section{Research Model}

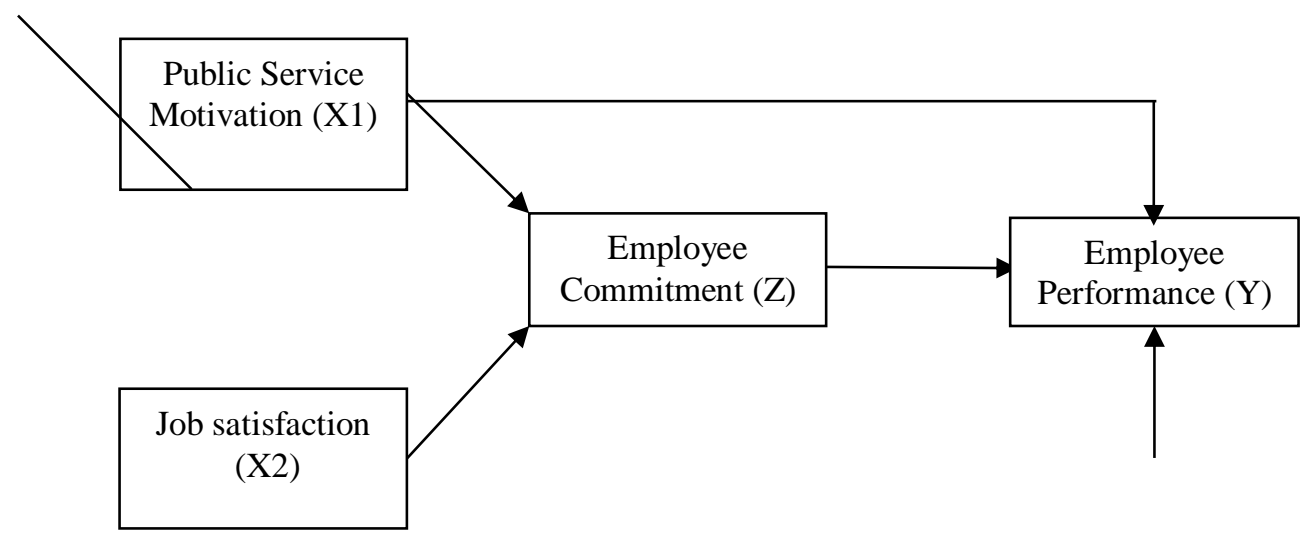

Figure 1. Research Framework

\section{Hypothesis}

H1 : Public service motivation affects employee commitment at Jabal Ghafur Sigli University.

H2 : Job satisfaction affects employee commitment at Jabal Ghafur Sigli University.

H3 : Public service motivation affects the performance of Jabal Ghafur Sigli University employees.

H4 : Job satisfaction affects employee performance at Jabal Ghafur Sigli University.

H5 : Employee commitment affects the performance of Jabal Ghafur Sigli University employees.

H6 : Employee commitment mediates the effect of motivation of public services on the performance of Jabal Ghafur Sigli University employees.

H7 : Employee commitment mediates the effect of job satisfaction on employee performance at Jabal Ghafur Sigli University

\section{RESEARCH METHOD}

The population was all employees of Jabal Ghafur University, totaling 41 employees. The number of samples is set at 41 employees. Sampling was carried out with a minimal sample formulation using the census technique. The data collection used in this research is using a personal 


\section{International Journal of Business Management and Economic Review}

Vol. 5, No. 01; 2022

ISSN: 2581-4664

questionnaire. In this study, questionnaires were distributed through the google form application to respondents through the WhatsApp group of each employee of Jabal Ghafur University. The respondents were asked to choose one of the alternative answer choices that the researcher had provided in the google form application.

The research hypothesis was tested using the Partial Least Square (PLS). According to (Latan \& Ghozali, 2012), "PLS is an alternative approach that shifts from a covariance-based SEM approach to a variance-based approach. PLS is more of a predictive model.

\section{RESULTS}

Validity Test

Table 2. Validity Test Results

\begin{tabular}{|c|c|c|c|c|c|}
\hline \multicolumn{2}{|c|}{ Indicator } & Variable & $\begin{array}{l}\text { Correlation } \\
\text { coefficient }\end{array}$ & $\begin{array}{l}\text { Critical Value } \\
5 \% \\
(\mathbf{N}=41)\end{array}$ & Note. \\
\hline 1. & 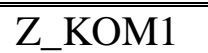 & \multirow{12}{*}{$\begin{array}{l}\text { Employee } \\
\text { Commitment } \\
\text { (Z) }\end{array}$} & 0.826 & \multirow{12}{*}{0.2632} & \multirow{12}{*}{ Valid } \\
\hline 2. & Z_KOM2 & & 0.908 & & \\
\hline 3. & Z_KOM3 & & 0.833 & & \\
\hline 4. & Z_KOM4 & & 0.719 & & \\
\hline 5. & Z_KOM5 & & 0.772 & & \\
\hline 6. & Z_KOM6 & & 0.873 & & \\
\hline 7. & Z_KOM7 & & 0.803 & & \\
\hline 8. & Z_KOM8 & & 0.775 & & \\
\hline 9. & Z_KOM9 & & 0.837 & & \\
\hline 10. & Z_KOM10 & & 0.909 & & \\
\hline 11. & Z_KOM11 & & 0.878 & & \\
\hline 12. & Z_KOM12 & & 0.759 & & \\
\hline 13. & Y_KP1 & \multirow{8}{*}{$\begin{array}{l}\text { Employee } \\
\text { Performance } \\
\text { (Y) }\end{array}$} & 0.868 & \multirow{8}{*}{0.2632} & \multirow{8}{*}{ Valid } \\
\hline 14. & Y_KP2 & & 0.855 & & \\
\hline 15. & Y_KP3 & & 0.717 & & \\
\hline 16. & Y_KP4 & & 0.792 & & \\
\hline 17. & Y_KP5 & & 0.648 & & \\
\hline 18. & Y_KP6 & & 0.760 & & \\
\hline 19. & Y_KP7 & & 0.729 & & \\
\hline 20. & Y_KP8 & & 0.718 & & \\
\hline 21. & X1_MPP1 & \multirow{9}{*}{$\begin{array}{l}\text { Public Service } \\
\text { Motivation } \\
\text { (X1) }\end{array}$} & 0.832 & \multirow{9}{*}{0.2632} & \multirow{9}{*}{ Valid } \\
\hline 22. & X1_MPP2 & & 0.791 & & \\
\hline 23. & X1_MPP3 & & 0.861 & & \\
\hline 24. & X1_MPP4 & & 0.865 & & \\
\hline 25. & X1_MPP5 & & 0.810 & & \\
\hline 26. & X1_MPP6 & & 0.891 & & \\
\hline 27. & X1_MPP7 & & 0.802 & & \\
\hline 28. & X1_MPP8 & & 0.809 & & \\
\hline 29. & X1_MPP9 & & 0.812 & & \\
\hline
\end{tabular}


International Journal of Business Management and Economic Review

Vol. 5, No. 01; 2022

ISSN: 2581-4664

\begin{tabular}{|c|c|c|c|c|c|}
\hline \multicolumn{2}{|c|}{ Indicator } & \multirow[t]{2}{*}{ Variable } & \multirow{2}{*}{$\begin{array}{l}\begin{array}{l}\text { Correlation } \\
\text { coefficient }\end{array} \\
0.776\end{array}$} & \multirow[t]{2}{*}{$\begin{array}{ll}\text { Critical } & \text { Value } \\
5 \% & \\
(\mathrm{~N}=41) & \\
\end{array}$} & \multirow[t]{2}{*}{ Note. } \\
\hline 30. & X1_MPP10 & & & & \\
\hline 31. & X2_KK1 & \multirow{13}{*}{$\begin{array}{l}\text { Job satisfaction } \\
\text { (X2) }\end{array}$} & 0.874 & \multirow{13}{*}{0.2632} & \multirow{13}{*}{ Valid } \\
\hline 32. & X2_KK2 & & 0.905 & & \\
\hline 33. & X2_KK3 & & 0.800 & & \\
\hline 34. & X2_KK4 & & 0.815 & & \\
\hline 35. & X2_KK5 & & 0.855 & & \\
\hline 36. & X2_KK6 & & 0.900 & & \\
\hline 37. & X2_KK7 & & 0.876 & & \\
\hline 38. & X2_KK8 & & 0.820 & & \\
\hline 39. & X2_KK9 & & 0.840 & & \\
\hline 40. & X2_KK10 & & 0.859 & & \\
\hline 41. & X2_KK11 & & 0.921 & & \\
\hline 42. & X2_KK12 & & 0.909 & & \\
\hline 43. & X2_KK13 & & 0.783 & & \\
\hline
\end{tabular}

Source: Primary Data, 2021

Based on table 2 above, explains all the variables used in this study are valid because they have a correlation coefficient above the critical value of product-moment correlation, which is 0.2632 so that all questions contained in this research questionnaire are declared valid for further research. more profound. Thus, all indicator items of each variable in this study have met the requirements for further testing.

\section{Reliability Test}

Table 3. Reliability Test Result

\begin{tabular}{|l|l|l|l|l|}
\hline No. & Variable & Variable Items & Alpha Value & Note: \\
\hline 1. & Public Service Motivation $(\mathrm{X} 1)$ & 10 & 0.947 & Reliable \\
\hline 2. & Job Satisfaction $(\mathrm{X} 2)$ & 13 & 0.969 & Reliable \\
\hline 3. & Employee Performance $(\mathrm{Y})$ & 8 & 0.888 & Reliable \\
\hline 4. & Employee Commitment $(\mathrm{Z})$ & 12 & 0.956 & Reliable \\
\hline
\end{tabular}

Source: Primary Data, 2021

Table 3 above shows the alpha value for each respondent's perception of Public Service Motivation (X1) obtained 0.947, Job Satisfaction (X2) 0.969, Employee Performance (Y) 0.888, and Employee Commitment (Z) 0.956. This reliability shows that all indicators of the research variables show that the measurement of reliability meets the credibility of Cronbach Alpha that is $>0.60$.

\section{Data Analysis Results}

Evaluation of Measurement (Outer) Model

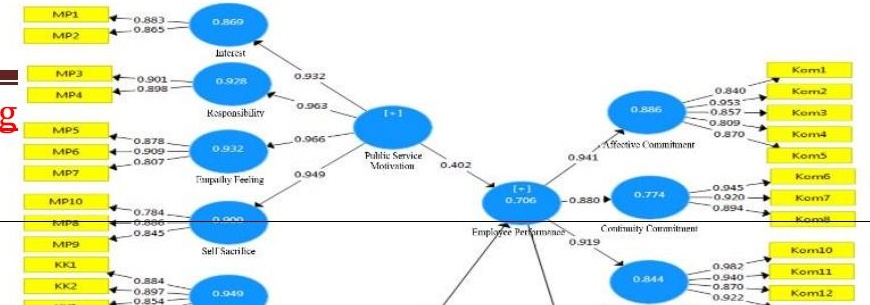


Figure 2. Structural Model

Table 4. Average Variance Extracted (AVE)

\begin{tabular}{|l|l|}
\hline Variable & AVE \\
\hline Public Service Motivation (X1) & 0.682 \\
\hline Job Satisfaction (X2) & 0.739 \\
\hline Employee Performance (Y) & 0.586 \\
\hline Employee Commitment (Z) & 0.684 \\
\hline
\end{tabular}

Source: Primary Data, 2021

The convergent validity using reflective indicators is assessed through the loading factor that explained as follows:

a. The construct of public service motivation shows the loading factor $>0.6$, and AVE $>0.5$.

b. The job satisfaction construct shows the loading factor $>0.6$, and AVE $>0.5$.

c. The employee performance construct shows the loading factor $>0.6$, and AVE $>0.5$.

d. The employee commitment construct shows the loading factor $>0.6$, and AVE $>0.5$.

The results conclude that the construct has good convergent validity.

Table 5. Composite Reliability

\begin{tabular}{|l|l|l|}
\hline Variable & $\begin{array}{l}\text { Cronbach's } \\
\text { Alpha }\end{array}$ & Composite Reliability \\
\hline Public Service Motivation (X1) & 0.948 & 0.955 \\
\hline Job Satisfaction (X2) & 0.970 & 0.973 \\
\hline Employee Performance (Y) & 0.897 & 0.918 \\
\hline Employee Commitment (Z) & 0.957 & 0.963 \\
\hline
\end{tabular}

Source: Data processing with PLS, 2021

A construct is declared reliable if it has a composite reliability value $>0.70$ and Cronbach's alpha $>0.60$. From the SmartPLS output, it is known that all constructs have a composite reliability value $>0.70$ and Cronbach's alpha $>0.60$. So it reveals that the construct has good reliability.

\section{Structural Model Testing (Inner) Model}

Table 6. R Square

\begin{tabular}{|l|l|}
\hline Variable & R Square \\
\hline $\mathrm{Y}$ & 0.781 \\
\hline
\end{tabular}


International Journal of Business Management and Economic Review

Vol. 5, No. 01; 2022

ISSN: 2581-4664

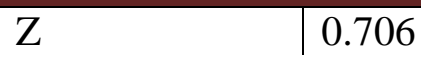

Based on the value of $\mathrm{R} 2$ in the table above, then the value of $Q$-square predictive relevance is:

$\mathrm{Q} 2=1-(1-0.781)(1-0.706)$

$\mathrm{Q} 2=1-(0.219)(0.294)$

$\mathrm{Q} 2=1-0.0643$

$\mathrm{Q} 2=0.9357$

Q2 has a value with a range of $0<\mathrm{Q} 2<1$, where the closer to 1 means the better whileR12, $\mathrm{R} 22, \ldots \mathrm{Rp} 2$ is the $\mathrm{R}$ square of endogenous variables. Structural Model Design of the relationship between latent variables is based on research problems or hypotheses. The value of Q2 in this study is 0.9357 , this figure is close to 1 . Thus, the observation value produced by the model is very good.

\section{Hypothesis test}

Table 7. Hypothesis Test Result

\begin{tabular}{|l|l|l|l|l|l|}
\hline Variable & $\begin{array}{l}\text { Origin } \\
\text { al } \\
\text { Sample }\end{array}$ & $\begin{array}{l}\text { Samp } \\
\text { le } \\
\text { Mean }\end{array}$ & $\begin{array}{l}\text { Standa } \\
\text { rd } \\
\text { Deviati } \\
\text { on }\end{array}$ & $\begin{array}{l}\text { T- } \\
\text { statisti } \\
\text { cs }\end{array}$ & $\begin{array}{l}\text { P- } \\
\text { value } \\
\text { s }\end{array}$ \\
\hline $\begin{array}{l}\text { Public Service Motivation (X1) } \rightarrow \\
\text { Employee Performance (Y) }\end{array}$ & 0.932 & 0.933 & 0.029 & 3,247 & 0.000 \\
\hline $\begin{array}{l}\text { Job Satisfaction (X2) } \rightarrow \text { Employee } \\
\text { Performance (Y) }\end{array}$ & 0.211 & 0.230 & 0.118 & 1,787 & 0.074 \\
\hline $\begin{array}{l}\text { Public Service Motivation (X1) } \rightarrow \\
\text { Employee Commitment (Z) }\end{array}$ & 0.402 & 0.400 & 0.131 & 3.062 & 0.002 \\
\hline $\begin{array}{l}\text { Job Satisfaction (X2) } \rightarrow \text { Employee } \\
\text { Commitment (Z) }\end{array}$ & 0.506 & 0.505 & 0.142 & 3,557 & 0.000 \\
\hline $\begin{array}{l}\text { Employee } \\
\text { Commitment(Z) } \rightarrow \text { Employee } \\
\text { Performance(Y) }\end{array}$ & 0.707 & 0.682 & 0.121 & 5,868 & 0.000 \\
\hline
\end{tabular}

Source: Data processing with PLS, 2021

Based on the results of the SmartPLS analysis the formulation provided is as follows:

Employee Commitment $=0.707$ Employee Performance

Employee Performance $=0.932$ Public Service Motivation +0.211 Job Satisfaction

\section{DISCUSSION OF HYPOTHESIS RESULTS}

Public Service Motivation and Employee Commitment (Hypothesis 1)

The effect test of public service motivation on commitment obtains $T$-statistics of 3.062 with a significance level of 0.002 . The coefficient is 0.402 or $40.2 \%$. Both values meet the requirements for the hypothesis acceptance, namely the probability of 0.002 is less than 0.05 . Thus, it can be concluded that the motivation of public services affects employee commitment.

This indicates that the better the motivation for public services will have a positive and real impact on increasing employee commitment. Jabal Ghafur University formulates and organizes 


\section{International Journal of Business Management and Economic Review}

Vol. 5, No. 01; 2022

ISSN: 2581-4664

various steps that can lift the motivation of employees in terms of public services to increase employee commitment.

The results of this study are in line with (Konya, Matic, \& Pavlovic, 2016) and (Sancaya, 2017) which show that the better the motivation in public services, the higher the employee's commitment to the organization.

\section{Job Satisfaction and Employee Commitment (Hypothesis 2)}

The effect test of satisfaction on employee commitment obtains $T$ - statistics of 3,557 with a significance level of 0.000 . The coefficient is 0.506 or $50.6 \%$. Both values meet the requirements for hypothesis acceptance, namely the probability of $0.000(<0.05)$. Thus, it can be concluded that satisfaction affects performance.

The results of this study are relevant to (Pandey \& Khare, 2012), (Iqbal, Tufail, \& Lodhi, 2015) and (Ajimat, 2019) stated that job satisfaction has a positive and significant effect on employee commitment.

\section{Public Service Motivation and Performance (Hypothesis 3)}

The effect test of public service motivation on performance obtains $T$-statistics of 3,247 with a significance level of 0.000 . The coefficient is 0.932 or $93.2 \%$. The two values meet the requirements for hypothesis acceptance, namely the probability of $0.000<0.05$. Thus, it reveals public service motivation affects performance. This indicates that the better the motivation for public services will have a positive and real impact on improving performance. Jabal Ghafur University arranges and organizes various steps that can lift the motivation of employees in terms of public services to improve the performance of their employees.

Relevant things were also expressed by (Lewicka et al., 2018). revealed that public service motivation is the basis for the productivity of an organization so that performance is maintained. In conditions of increasing competition, well-designed jobs will be able to attract and retain performance and provide motivation to produce quality products and services. This encourages employee creativity (Silvia et al., 2014), (Lewicka et al., 2018). Thus, the better the motivation for public services in an organization, the higher the performance of employees in an organization. Vice versa, the more irregular the motivation of public services in an organization, the lower the employee's performance.

\section{Job Satisfaction and Performance (Hypothesis 4)}

The effect test of satisfaction on performance obtains T - statistics is 1.787 (should be > 1.96) with a significance level of 0.074 (should be less than 5\%). The coefficient is 0.211 or $21.1 \%$. Both values meet the requirements for hypothesis acceptance, namely the probability of 0.074 greater than 0.05 . Thus, it concludes that satisfaction does not affect performance.

The results of this study are relevant to (Fakhraei, \& Manuchehri, 2015) and Mustafa et al. (2015) where the results of the study show that job satisfaction does not affect performance. This shows that satisfaction is not always able to increase employee commitment in the world of work. Not infrequently found, the higher satisfaction obtained by employees makes their commitment to the organization decrease. 
International Journal of Business Management and Economic Review

Vol. 5, No. 01; 2022

ISSN: 2581-4664

\section{Employee Commitment and Performance (Hypothesis 5)}

The effect test of commitment on performance obtains a significance value of 0.000 . The coefficient is 0.707 or $70.7 \%$. The two values meet the requirements for hypothesis acceptance, namely the probability of 0.000 is less than 0.05 . Thus, it concludes that employee commitment affects performance. This indicates that the better the employee's commitment will have a positive and real impact on improving performance.

(Dixit \& Bhati, 2012) found that Employee Commitment (Affective, Normative, Sustainable) is significantly related to sustainable productivity in the auto component industry and they reported that there was a relationship between the three commitments (affective, continuity, and normative commitment) and sustainable organizational productivity. (Qaisar, Masood, \& Rashid, 2017) examined the effect of three components of employee commitment (affective, continuous, and normative) on the performance of police officers in Pakistan.

(Sinclair, Unruh, Lindstrom, \& Scanlon, 2015) draw from previous research on employee commitment to propose an effective framework and continuation profile of commitment. They reported that free agents received significantly worse ratings of supervisor performance, organizational citizenship behavior, and antisocial behavior than the other groups. (Suliman \& Iles, 2000) explore the nature of employee commitment in three industrial units in Jordan by applying performance and five demographic variables. The findings also find a positive relationship between commitment and performance."

\section{Employee Commitment Mediates the Public Service Motivation and Performance (Hypothesis 6)}

In this study, there is an intervening variable (mediation), namely employee commitment. According to (Sekaran \& Bougie, 2016), the mediating the relationship between the independent variable and the dependent variable. The mediation test is used to prove the role of employee commitment as an intervening variable that functions to mediate the relationship between the variables of public service motivation and satisfaction on performance. Testing the mediation hypothesis was carried out using Sobel Test (Sobel, 1982). The following is a test of the mediating effect of the public service motivation variable mediated by employee commitment to performance, which can be explained as follows:

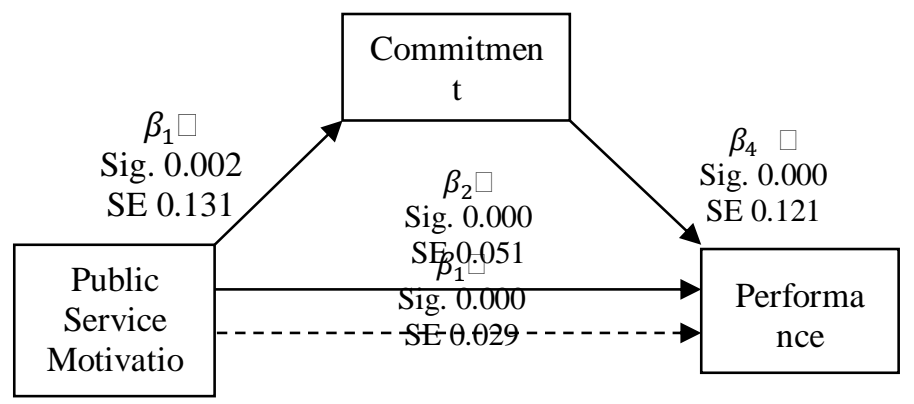

Figure 3. Mediation Test of Hypothesis 6

Figure 3 above is a model formed. The $\mathrm{z}$ value is generated by manual calculation using the Sobel test formula. The results are: 
International Journal of Business Management and Economic Review

Vol. 5, No. 01; 2022

ISSN: 2581-4664

$$
\begin{aligned}
\hline \hline Z=\frac{a 1 b 1}{\sqrt{\left(b 1^{2} \text { SEa } 1^{2}\right)+\left(a 1^{2} S E b 1^{2}\right)}} \\
Z=\frac{(0,402)(0,707)}{\sqrt{\left((0,707)^{2}(0,131)^{2}\right)+\left((0,402)^{2}(0,121)^{2}\right)}} \\
Z=\frac{0,2842}{\sqrt{(0,4998)(0,0171)+(0,1616)(0,0146)}} \\
Z=\frac{0,2842}{\sqrt{0,0085+0,0023}} \\
Z=\frac{0,2842}{\sqrt{0,0108}} \\
Z=\frac{0,2842}{0,3057} \\
Z=0.9296
\end{aligned}
$$

From the calculation above, it was found that the $\mathrm{z}$ value was $0.9296<1.96$ with a significance level of 5\%. These results indicate that there is a direct influence between public service motivation on performance which is mediated by full employee commitment (fully mediation). This indicates that the independent variable in testing using this Sobel test, namely the motivation of public services is not able to significantly influence the dependent variable, namely performance without going through a mediator variable, namely employee commitment.

The influence of public service motivation on performance can occur directly (directly) or indirectly (indirectly) through employee commitment. This rationale is supported by empirical literature based on the results of previous research such as Kónya et al., (2016)which proves that public service motivation can affect employee commitment. Research result Sancaya (2017) also strengthens the empirical basis on the existence of a functional relationship between the two variables.

\section{Employee Commitment Mediates Job Satisfaction and Performance (Hypothesis 7)}

The following is a test result of the mediating effect of satisfaction variables mediated by an organizational commitment on performance using the Sobel Test procedure, which can be explained as follows:

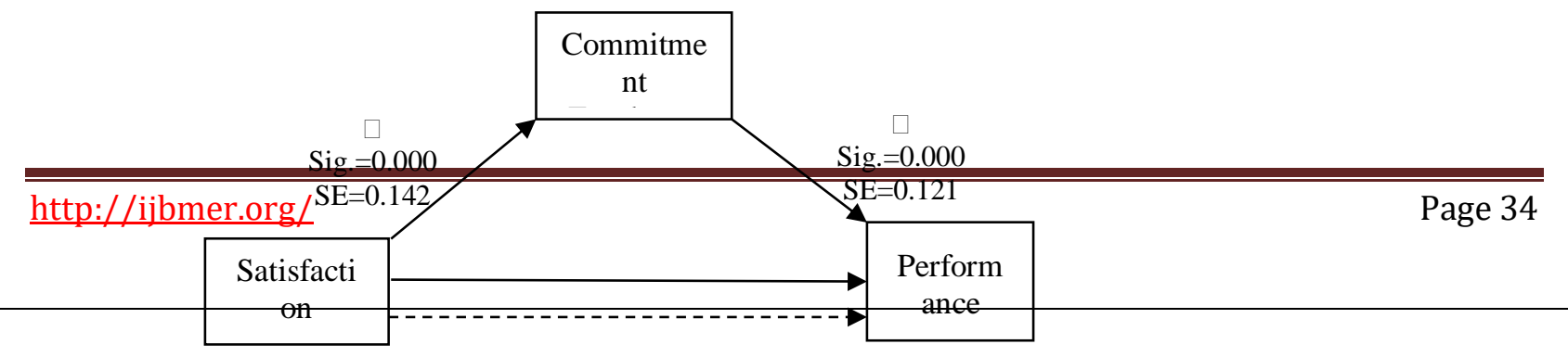




$$
\begin{gathered}
\text { Sig. }=0.000 \\
\text { SE }=0.075
\end{gathered}
$$

Sig. $=0.074$

$\mathrm{SE}=0.118$

Figure 4. Mediation Test of Hypothesis 7

Figure 4 above is a model formed. The $\mathrm{z}$ value is generated by manual calculation using the Sobel test formula. The results are:

$$
\begin{aligned}
\mathrm{Z}=\frac{a 1 b 1}{\sqrt{\left(b 1^{2} S E a 1^{2}\right)+\left(a 1^{2} S E b 1^{2}\right)}} \\
\mathrm{Z}=\frac{(0,506)(0,707)}{\sqrt{\left((0,707)^{2}(0,142)^{2}\right)+\left((0,506)^{2}(0,121)^{2}\right)}} \\
\mathrm{Z}=\frac{0,3577}{\sqrt{(0,4998)(0,0201)+(0,2560)(0,0146)}} \\
\mathrm{Z}=\frac{0,3577}{\sqrt{0,0100+0,0037}} \\
\mathrm{Z}=\frac{0,3577}{\sqrt{0,0137}} \\
\mathrm{Z}=\frac{0,3577}{0,1170} \\
\mathrm{Z}=3.057
\end{aligned}
$$

From the calculation above, it was found that the $\mathrm{z}$ value was $3.057>1.96$ with a significance level of 5\%. These results indicate there is an indirect effect between satisfaction on performance mediated by partial mediation of employee commitment. This indicates that the independent variable in testing using this Sobel test, namely satisfaction can directly affect the dependent variable, namely performance without going through or involving a mediator variable, namely employee commitment.

As explained earlier, satisfaction can affect employee commitment. Empirically the functional relationship between the two variables has been strengthened by the findings of Pandey \& Khare (2012), Iqbal et al., (2015), and Amulet (2019), who stated that job satisfaction has a positive and significant effect on employee commitment. Furthermore, several empirical studies also prove the effect of employee commitment on performance.

\section{CONCLUSION}

Several conclusions from this study can be drawn as follows:

1. Public service motivation affects employee commitment at Jabal Ghafur University. This indicates that the better the motivation for public services will have a positive real impact on increasing employee commitment. Jabal Ghafur University formulates and organizes various 


\section{International Journal of Business Management and Economic Review}

Vol. 5, No. 01; 2022

ISSN: 2581-4664

steps that can lift the motivation of employees in terms of public services to increase employee commitment.

2. Job satisfaction affects employee commitment at Jabal Ghafur University. This indicates that the better the job satisfaction felt by the employees, it will have a positive real impact on employee commitment to Jabal Ghafur University.

3. Public service motivation affects the performance of Jabal Ghafur Sigli University employees. This indicates that the better the employees in having public service motivation at work will have a positive real influence on improving the performance of employees to employees Jabal Ghafur Sigli University.

4. Satisfaction does not affect the performance of Jabal Ghafur Sigli University employees. This indicates that the satisfaction felt by employees is different so that not all feel the same. This reality is contrary to the performance that can be given to the University of Jabal Ghafur Sigli so that the job satisfaction provided by the organization does not affect the performance improvement of its employees.

5. Employee commitment affects the performance of Jabal Ghafur Sigli University employees. This indicates that the better the commitment possessed by the employees Jabal Ghafur Sigli University will have a positive and significant impact on improving performance.

6. Employee commitment mediates the effect of public service motivation on the performance of Jabal Ghafur Sigli University employees. These result explains that there is an indirect influence between public service motivation on performance which is mediated by full employee commitment (fully mediation, because hypothesis 4 is not accepted).

7. Employee commitment mediates the effect of satisfaction on the performance of Jabal Ghafur Sigli University employees. These results reveals that there is an indirect effect between satisfaction on performance mediated by employee commitment (partial mediation).

Furthermore, the authors provide the following suggestions:

1. In the employee performance variable, there is an indicator that the response acceleration is still lacking, namely the skills possessed by employees in completing tasks. The steps that can be taken by Jabal Ghafur University to overcome this are by conducting continuous training programs, adjusting work according to abilities and interests, clearly conveying the goals and targets of Jabal Ghafur University, giving appreciation and motivation, conducting supervision, and conduct periodic performance evaluations.

2. There are several indicators of affective, continuity, and normative dimensions that still need to be improved to form high employee commitment. Jabal Ghafur University must increase the commitment of its employees to work. Responding to the results of respondents in this study, the University of Jabal Ghafur should take various steps to overcome this, such as routine leadership in reviewing the performance of their subordinates, finding solutions to the lack of commitment of employees, and giving prizes for performance, contributing to every activity carried out, and pay attention to employees in every activity that takes place.

3. In the variable of public service motivation, several facts must be improved and improved. Emphasis on the importance of the role of employees who serve the public in the form of providing training, debriefing, self-development so that they are more ready and wholehearted in their duties. Furthermore, the employees who serve in the public service department at Jabal Ghafur University will expect attention from the leaders on their performance, help them when 
they have difficulties at work, and don't forget to give rewards for employees who wholeheartedly and work optimally.

4. In the variable of job satisfaction, the dimensions of comfort in working conditions, adequate work equipment, skills, and opportunities to get promotions still need to be accelerated.

5. Practical suggestions that can be given to related organizations include that the results can be used as consideration for improvement in employee performance with the existence of public service motivation and satisfaction owned by employees so that later it can be achieved even better while still emphasizing the commitment of the Jabal Ghafur University employee.

\section{REFERENCES}

Afriani, F., \& Kasmiruddin. (2017). Pengaruh Keterlibatan Kerja dan Loyalitas Karyawan terhadap Kinerja Karyawan (pada Karyawan Bank Uob Cabang Pekanbaru). JOM FISIP, $4(1), 34-54$.

Ajimat. (2019). Peran Komitmen Organisasi Dalam Pengaruh Negatif Turnover Intention Terhadap Loyalitas Karyawan (Studi Kasus di Universitas Pamulang). Jurnal Ekonomi Efektif, 2(1), 94-100. https://doi.org/http://dx.doi.org/10.32493/JEE.v2i1.3506

Crewson, P. E. (1997). Public Service Motivation: Building Empirical Evidence of Incidence and E ect. Journal of Public Administration Research and Theory, 7(4), 499-518. https://doi.org/10.1093/oxfordjournals.jpart.a024363

Dixit, V., \& Bhati, M. (2012). A study about employee commitment and its impact on sustained productivity in Indian auto-component industry. Europan Journal of Business and Social Sciences, 1(6), 34-51.

Dizgah, M. R., Chegini, M. G., \& Bisokhan, R. (2012). Relationshipbetween Job Satisfaction and Employee Job Performance in Guilan Public Sector. Journal of Basic and Applied Scientific Research, 2(2), 1735-1741.

Fadlallh, A. W. A. (2015). Impact of Job Satisfaction on Employees Performance an Application on Faculty of Science and Humanity Studies University of Salman Bin Abdul-Aziz-Al Aflaj. International Journal of Innovation and Research in Educational Sciences, 2(1), 26-32.

Fakhraei, \& Manuchehri, S. (2015). Effects of organizational justice on organizational commitment. International Journal of Economics and Financial Issues, 6(3), 188-196.

Gomes, F. C. (2003). Manajemen sumber daya manusia. Yogyakarta: Andi.

Iqbal, A., Tufail, M. S., \& Lodhi, R. N. (2015). Employee Loyalty And Organizational Commitment In Pakistani Organizations. Global Journal Of Human Resource Management, $3(1), 1-11$.

Jankingthong, K., \& Rurkkhum, S. (2012). Factors Affecting Job Performance: A Review of Literature. Silpakorn University Journal of Social Sciences, Humanities, and Arts, 12(2), $115-127$.

Konya, V., Matic, D., \& Pavlovic, J. (2016). The Influence of Demographics, Job Characteristics and Characteristics of Organizations on Employee Commitment. Acta Polytechnica Hungarica, 13(3), 119-138.

Kónya, V., Matić, D., \& Pavlović, J. (2016). The influence of demographics, job characteristics and characteristics of organizations on employee commitment. Acta Polytechnica Hungarica, 13(3), 119-138.

Kreitner, R., \& Kinicki, A. J. (2013). Perilaku Organisasi Bk.2 (9th ed.). Jakarta: Salemba Empat. 


\section{International Journal of Business Management and Economic Review}

Vol. 5, No. 01; 2022

ISSN: 2581-4664

Latan, H., \& Ghozali, I. (2012). Partial Least Square: Konsep, Teknik, dan Aplikasi SmartPLS 2.0 M3. Semarang: Badan Penerbit Universitas Diponogero.

Lewicka, D., Glinska-Newes, A., Morrow, D. L., \& Gorka, J. (2018). The effect of job characteristics on employee loyalty: the mediation role of vertical trust and perceived supervisory support. Marketing and Management of Innovations, 2, 168-185. https://doi.org/10.21272/mmi.2018.2-14

Luthans, F. (2013). Organizational Behavior An Evidence-Based Approach (8th ed.). New York: Mc Graw Hill.

Meyer, J. P., \& Allen, N. J. (1997). Commitment in the Workplace: Theory, Research, and Application. https://doi.org/http://dx.doi.org/10.4135/9781452231556

Pandey, C., \& Khare, R. (2012). Impact of Job Satisfaction and Organizational. International Journal of Social Science \& Interdisciplinary Research, 1(8), 26-41.

Perry, J. L., \& Hondeghem, A. (2008). otivation in Public Management: The Call of Public Service. New York: Oxford University Press.

Qaisar, S., Masood, A., \& Rashid, S. (2017). Problematic Mobile Phone Use, Academic Procrastination and Academic Performance of College Students. Journal of Educational Research, 20(2), 201-214.

Rainey, H. G., \& Steinbauer, P. (1999). Galloping Elephants: Developing Elements of a Theory of Effective Government Organizations. Journal of Public Administration Research and Theory, 9, 1-32. https://doi.org/https://doi.org/10.1093/oxfordjournals.jpart.a024401

Ram, P. (2017). Relationship between Job Satisfaction and Job Performance in the Public SectorA Case Study from India. International Journal of Academic Research in Economics and Management Sciences, 2(2), 16-35.

Respatiningsih, I., \& Sudirjo, F. (2015). Pengaruh Komitmen Organisasi, Motivasi, Kapabilitas dan Kepuasaan Kerja Terhadap Kinerja Pegawai (Studi Empirik pada Inspektorat Kabupaten Pemalang. Serat Acitya (Jurnal Ilmiah), 4(3), 56-58.

RI PP. (2019). Penilaian Kinerja Pegawai Negeri Sipil (PNS).

Robbins, S. P., \& Judge, T. A. (2017). Essential of Organisational Behaviour (14th ed.). New Jersey: Pearson.

Salwa, A., Away, Y., \& Tabrani, M. (2018). Pengaruh Komitmen, Integritas Dan Kompetensi Terhadap Kinerja Pegawai Serta Dampaknya Pada Kinerja Komisi Independen Pemilihan (KIP) Aceh. Jurnal Magister Manajemen, 2(1), 58-67.

Sancaya, I. G. N. W. (2017). Pengaruh Karakteristik Personal Dan Karakteristik Pekerjaan Terhadap Komitmen Organisasi Karyawan Pengerajin Kain Tenun Endek Di Pelangi Traditional Weaving Sidemen Tahun 2016. Jurnal Pendidikan Ekonomi Undiksha, 10(2), 490. https://doi.org/10.23887/jjpe.v10i2.20092

Saputra, B., \& Sripto. (2018). Pengaruh Motivasi Pelayanan Publik dan Kompetensi Terhadap Kinerja Aparatur Sipil Negara RSUD Kabupaten Pasaman Barat. Jurnal Magister Administrasi Publik Universitas Gadjah Mada, 21, 723-743.

Sekaran, U., \& Bougie, R. (2016). Research Methods For Business: A Skill Building Approach (7th ed.). New Jersey: Wiley.

Silvia et al. (2014). Pengaruh Kompensasi dan Karakteristik Pekerjaan Terhadap Loyalitas Karyawan (Studi Kasus Pada Toko Buku Gramedia Pangkalpinang). Jurnal Progresif Manajemen Bisnis, 1(1), 1-10. 
Vol. 5, No. 01; 2022

ISSN: 2581-4664

Sinclair, J., Unruh, D., Lindstrom, L., \& Scanlon, D. (2015). Barriers to Sexuality for Individuals with Intellectual and Developmental Disabilities: A Literature Review. Education and Training in Autism and Developmental Disabilitites, 50(1), 3-16.

Sobel, M. E. (1982). Asymptotic Confidence Intervals for Indirect Effects in Structural Equation Models. Sociological Methodology, 290-321. https://doi.org/https://doi.org/10.2307/270723

Soetrisno, E. (2016). Manajemen Sumber Daya Manusia (Cetakan Ke). Jakarta: Prenada Media Gorup.

Sopiah, \& Sangadji, E. M. (2018). Manajemen Sumber Daya Manusia Strategik. Yogyakarta: Andi Publisher.

Suliman, A., \& Iles, P. (2000). Is continuance commitment beneficial to organizations? Commitment-performance relationship: A new look. Journal of Managerial Psychology, 15(5), 407-422. https://doi.org/10.1108/02683940010337158

Suwanto, \& Priansa, D. J. (2016). Manajemen SDM dalam Organisasi Publik dan Bisnis. Bandung: Alfabeta.

Vandenabeele, W., Scheepers, S., \& Hondeghem, A. (2006). Public Service Motivation in an International Comparative Perspective: The UK and Germany. Public Policy and Administration, 21(1), 13-31. https://doi.org/10.1177/095207670602100102 